\title{
Faktor-Faktor yang Mempengaruhi Kepatuhan WPOP Pelaku E-Commerce di Kota Semarang pada Platform Online Marketplace Blibli.com
}

\author{
Putri Dwi Indriyani' ${ }^{1}$, Prabowo Yudo Jayanto ${ }^{2}$ \\ ${ }^{1,2}$ Jurusan Akuntansi, Fakultas Ekonomi, Universitas Negeri Semarang \\ 1e-mail: putridwiindriyani0@gmail.com \\ 2e-mail: yudho@mail.unnes.ac.id

\begin{tabular}{ccc}
\hline Diterima & Direvisi & Disetujui \\
$11-02-2020$ & $23-02-2020$ & $19-03-2020$ \\
\hline
\end{tabular}

\begin{abstract}
Abstrak - Berkembangnya perdagangan secara online didasarkan atas kemudahan bagi pelaku bisnis dalam mempromosikan barangnya serta tidak memerlukan biaya yang lebih karena tidak dibutuhkan adanya toko secara fisik. Kegiatan jual beli barang dan/atau jasa melalui media internet dikenal dengan electronic commerce (selanjutnya disebut e-commerce). Penelitian ini bertujuan untuk menganalisis dan memperoleh bukti empiris mengenai pengaruh variabel sosialisasi perpajakan, pemahaman perpajakan, kesadaran wajib pajak, dan sanksi pajak terhadap kepatuhan pelaku e-commerce di Kota Semarang pada platform online marketplace Blibli.com. Populasi penelitian ini adalah wajib pajak orang pribadi pelaku e-commerce di Kota Semarang pada platform online marketplace Blibli.com. Teknik pengambilan sampel menggunakan non-probability sampling dengan metode voluntary sampling. Sampel yang diperoleh sebanyak 65 responden. Teknik analisis data yang digunakan adalah analisis Structural Equation Modelling (SEM) berbasis Partial Least Square (PLS) dengan alat analisis SmartPLS 3.0. Penelitian ini menunjukkan bahwa sosialisasi perpajakan berpengaruh negatif dan tidak signifikan terhadap kepatuhan pelaku e-commerce dalam memenuhi kewajiban perpajakan. Pemahaman perpajakan dan kesadaran wajib pajak berpengaruh positif dan signifikan serta sanksi pajak berpengaruh positif namun tidak siginfikan terhadap kepatuhan pelaku e-commerce dalam memenuhi kewajiban perpajakan.
\end{abstract}

\section{Kata Kunci: Kepatuhan Wajib Pajak E-Commerce}

\begin{abstract}
The development of online trading is based on the ease for businesses to promote their goods and does not require more costs because there is no need for a physical store. The activity of buying and selling goods and / or services through internet media is known as electronic commerce (hereinafter referred to as ecommerce).This study aims to analyze and obtain empirical evidence about the influence of the variable tax socialization, understanding of taxation, awareness of taxpayers, and tax sanctions on the compliance of ecommerce actors in the city of Semarang on the BliBli.com online marketplace platform. The population of this research is e-commerce individual taxpayers in the city of Semarang on the Blibli.com online marketplace platform. The sampling technique uses non-probability sampling with voluntary sampling method. Samples obtained were 65 respondents. The data analysis technique used is Structural Equation Modeling (SEM) analysis based on Partial Least Square (PLS) with SmartPLS 3.0 analysis tools. This study shows that tax socialization has a negative and not significant effect on the compliance of e-commerce actors in fulfilling tax obligations. Understanding taxation and awareness of taxpayers has a positive and significant effect and tax sanctions have a positive but not significant effect on the compliance of e-commerce actors in meeting tax obligations.
\end{abstract}

Keywords: E-Commerce Taxpayer Compliance

\section{PENDAHULUAN}

Seiring perkembangan teknologi dan informasi, kini berbagai transaksi perdagangan barang atau jasa dapat dilakukan secara online. Berkembangnya perdagangan secara online didasarkan atas kemudahan bagi pelaku bisnis dalam mempromosikan barangnya serta tidak memerlukan biaya yang lebih karena tidak dibutuhkan adanya toko secara fisik. Kegiatan jual beli barang dan/atau jasa melalui media internet dikenal dengan electronic commerce (selanjutnya disebut e-commerce). Transaksi e-commerce dapat diakses dengan mudah dimanapun dan kapanpun melalui berbagai media elektronik seperti laptop, komputer, bahkan gadget, sehingga banyak sekali bisnis online, dapat dilihat dari terus meningkatnya e-commerce di era digital saat ini. E-commerce menyumbang 10,2 persen dari total penjualan ritel global pada tahun 2017, meningkat menjadi 11,9 
persen di tahun 2018, diperkirakan pada tahun 2019 ini mencapai 13,7 persen dan pada tahun 2021 mendatang diprediksi akan mencapai 17,5 persen

Kemajuan teknologi pada era globalisasi memberikan berbagai kemudahan bagi para pelaku bisnis, namun hal tersebut bukan tanpa risiko, kekurangan, dan kendala. Salah satu kendala yang dihadapi adalah permasalahan dalam bidang pajak. Pemerintah menghadapi tantangan tersendiri dalam menangani permasalahan pajak, khususnya pajak penghasilan e-commerce, karena kemajuan yang pesat di dunia usaha tidak selalu diikuti dengan kemajuan yang sama dalam bidang hukum. Perlu adanya regulasi yang mengatur masalah perpajakan e-commerce sehingga terdapat payung hukum yang jelas mengenai transaksi $e$-commerce.

Suatu kegiatan bisnis yang mendatangkan keuntungan, seperti transaksi jual beli online tidak akan terlepas dari pengenaan pajak, khususnya pajak penghasilan pihak penjual. Transaksi $e$ commerce memiliki implikasi pajak yang sedikit rumit, misalnya dalam hal pengawasan. Jumlah pelaku e-commerce dan berapa jumlah nominal transaksi e-commerce tidak mudah untuk diketahui dan dipantau, sehingga berdampak juga dalam hal pajak. Kendala tersebut disebabkan masih minimnya kemampuan teknologi informasi dalam bidang pengawasan dan kemampuan sumber daya manusia.

Pajak merupakan komponen penting dalam penerimaan negara. Pajak menyumbang sekitar $75 \%$ dari seluruh penerimaan negara.Persentase tersebut terus meningkat dari tahun ke tahun. Melansir data yang disajikan di Laporan Keuangan Pemerintah Pusat (LKPP), pada tahun 2015 realisasi penerimaan perpajakan hanyalah sebesar $83,29 \%$ dari target. Dalam tiga tahun berikutnya $(2016,2017,2018)$ realisasi penerimaan perpajakan adalah masing-masing sebesar 83,48\%, 91,23\%, dan $93,86 \%$. Meskipun demikian, rasio pajak Indonesia merupakan rasio terendah di dunia yaitu 11\% (Kevin, 2019).

Direktur Jenderal Pajak telah mengeluarkan beberapa surat edaran untuk menegaskan kewajiban pembayaran pajak penghasilan dari e-commerce, diantaranya Surat Edaran Direktur Jenderal Pajak Nomor S-429/PJ.22/1998 tanggal 24 Desember 1998 Tentang Imbauan Kepada Wajib Pajak yang Melakukan Transaksi Melalui Electronic Commerce, Surat Edaran Direktur Jenderal Pajak Nomor SE-62/PJ/2013 Tentang Penegasan Ketentuan Perpajakan atas Transaksi E-Commerce, dan Surat Edaran Nomor SE-06/PJ/2015 tentang Pemotongan dan/atau Pemungutan Pajak Penghasilan Atas Transaksi E-Commerce. Namun sepertinya keberadaan dari surat edaran yang dimaksud tidak dapat memberikan implikasi hukum yang lebih kuat mengatur kepatuhan pelaku $e$ commerce. Pada kenyataannya, penerapan dari surat edaran yang menegaskan kewajiban dengan total penjualan retail dari e-commerce mencapai US\$ 4,9 miliar (Clement, 2019).

pembayaran pajak tersebut masih belum dapat dinilai apakah telah diberlakukan dengan maksimal mengingat sistem pemungutan pajak penghasilan adalah sistem self assessment dimana memberikan wewenang kepada wajib pajak untuk menghitung, memperhitungkan, membayar, dan melaporkan sendiri besarnya pajak yang terutang. Sehingga, apabila Direktorat Jenderal Pajak tidak memiliki data lain selain yang dilaporkan oleh wajib pajak, maka laporan wajib pajak dianggap benar.

Melihat fenomena gap yang terjadi, penelitian untuk mengetahui faktor-faktor apa saja yang mampu mempengaruhi tingkat kepatuhan wajib pajak orang pribadi pelaku e-commerce dirasa perlu untuk dilakukan. Penelitian ini menggunakan tiga pendekatan teori dengan tujuan untuk menguji dan menganalisis bagaimana perilaku seseorang bisa diwujudkan menjadi suatu tindakan yang nyata dalam melakukan pemenuhan kewajiban perpajakannya. Menurut teori kepatuhan (compliance theory) secara umum menjelaskan suatu kondisi dimana seseorang taat terhadap perintah atau aturan yang diberikan. Terdapat dua perspektif yaitu instrumental dan normatif. Perspektif instrumental mengasumsikan individu secara utuh didorong oleh kepentingan pribadi dan tanggapan terhadap perubahan-perubahan yang berhubungan dengan perilaku. Perspektif normatif berhubungan dengan apa yang orang anggap sebagai moral dan berlawanan dengan kepentingan pribadi. Seorang individu cenderung mematuhi hukum yang mereka anggap sesuai dan konsisten dengan norma-norma internal mereka (Milgram, 1963).

Pendekatan kedua yang digunakan dalam penelitian ini adalah teori atribusi yang secara umum menjelaskan apakah perilaku seseorang disebabkan pihak internal maupun eksternal. Perilaku yang disebabkan secara internal merupakan perilaku yang diyakini berada di bawah kendali pribadi seorang individu. Perilaku yang disebabkan secara eksternal merupakan perilaku yang dianggap sebagai akibat dari sebab-sebab luar, yaitu individu secara tidak langsung atau dianggap telah dipaksa berperilaku demikian oleh situasi (Heider, 1958).

Pendekatan lain yang digunakan dalam penelitian ini adalah Theory of Planned Behavior (TPB). Secara umum teori ini menyatakan bahwa perilaku yang dilakukan individu muncul karena adanya niat untuk melakukan tindakan tersebut. Hal ini didasarkan pada asumsi bahwa manusia biasanya bertindak atau berperilaku sesuai dengan pemahaman mereka (apa yang mereka pahami). Theory of Planned Behavior (TPB) menjelaskan bahwa perilaku wajib pajak yang tidak patuh (non compliance) sangat dipengaruhi oleh variabel dari 
sikap, norma subyektif, serta kontrol keperilakuan yang dipersepsikan (Ajzen, 1991).

Sosialisasi perpajakan adalah upaya Direktorat Jenderal Pajak untuk memberikan pengetahuan kepada masyarakat dan khususnya Wajib Pajak agar mengetahui tentang segala hal mengenai perpajakan baik peraturan maupun tata cara perpajakan melalui metode-metode yang tepat (Saragih, 2013). Kegiatan sosialisasi perpajakan dapat dilakukan melalui sosialisasi langsung dengan berinteraksi langsung dengan wajib pajak dan juga dapat melalui sosialisasi tidak langsung yaitu kegiatan sosialisasi perpajakan dengan tidak atau sedikit melakukan interaksi dengan wajib pajak (Herryanto \& Toly, 2013).

Berdasarkan teori atribusi, pengaruh sosialisasi perpajakan terhadap kepatuhan wajib pajak orang pribadi pelaku e-commerce dalam memenuhi kewajiban perpajakan.Sosialisasi perpajakan dipengaruhi oleh faktor eksternal. Sosialisasi diberikan oleh petugas pajak yang diharapkan mampu memberikan dampak berupa taat dan patuhnya wajib pajak dalam menyelesaikan kewajiban perpajakannya. Wajib pajak yang aktif dalam kegiatan sosialisasi diharapkan semakin meningkatkan kepatuhan perpajakannya.

Indikator yang digunakan untuk mengukur variabel sosialisasi perpajakan diadopsi dan dimodifikasi dari (Jannah, 2016) yaitu penyelenggaraan sosialisasi, media sosialisasi, dan manfaat sosialisasi.

Berdasarkan penelitian yang dilakukan Setiyoningrum et al. (2014), Ananda et al. (2015), dan Banamtuan (2018) membuktikan bahwa sosialisasi perpajakan memiliki pengaruh signifikan terhadap kepatuhan wajib pajak orang pribadi. Tidak sejalan dengan penelitian yang dilakukan Alfasadun et al. (2016) dimana sosialisasi perpajakan tidak berpengaruh terhadap kepatuhan wajib pajak.

\section{$\mathrm{H}_{1}$ : Sosialisasi Perpajakan berpengaruh positif dan signifikan terhadap Kepatuhan Pelaku E- Commerce Dalam Memenuhi Kewajiban Perpajakan}

Pengetahuan pajak adalah proses pengubahan sikap dan tata laku wajib pajak dalam usaha mendewasakan manusia melalui upaya pengajaran dan pelatihan. Pengetahuan akan peraturan perpajakan masyarakat melalui pendidikan formal maupun non formal akan berdampak positif terhadap kesadaran wajib pajak untuk membayar pajak. Menurut (Kamil, 2015) kepatuhan wajib pajak akan meningkat apabila pengetahuan tentang pajak seseorang ditingkatkan.

Berdasarkan teori kepatuhan (compliance theory), seorang individu cenderung mematuhi hukum yang mereka anggap sesuai dan konsisten dengan norma-norma internal mereka (Marlinah,
2018). Pemahaman perpajakan termasuk dalam komitmen normatif melalui moralitas personal (normative commitment through morality) yang berarti wajib pajak mematuhi hukum karena hukum tersebut dianggap sebagai suatu keharusan. Sehingga apabila pemahaman perpajakan meningkat, maka kepatuhan wajib pajak juga akan meningkat.

Teori atribusi juga mendukung pengaruh pemahaman perpajakan terhadap kepatuhan wajib pajak orang pribadi pelaku e-commerce dalam memenuhi kewajiban perpajakan. Berdasarkan teori atribusi, dinyatakan bahwa pemahaman wajib pajak tentang peraturan perpajakan merupakan penyebab internal yang dapat mempengaruhi persepsi wajib pajak dalam membuat keputusan terkait perilaku kepatuhan wajib pajak dalam melaksanakan kewajiban perpajakan. Masyarakat yang paham tentang perpajakan tentuakan membayar pajak secara sukarela tanpa ada paksaan dan sadar akan pemenuhan kewajiban perpajakannya karena merasa tidak adanya kerugian dalam pemungutan pajak yang dilakukan.

Indikator yang digunakan untuk mengukur variabel pemahaman perpajakan diadopsi dan dimodifikasi dari (Priambodo \& Yushita, 2017) yaitu pengetahuan mengenai ketentuan umum dan tata cara perpajakan, pengetahuan mengenai sistem perpajakan, dan pengetahuan mengenai fungsi perpajakan.

Menurut penelitian yang dilakukan Karuniawati (2016) dan Dewi \& Merkusiwati (2018) pengetahuan pajak berpengaruh positif terhadap kepatuhan wajib pajak. Semakin paham wajib pajak terhadap peraturan perpajakan, maka semakin patuh wajib pajak dalam memenuhi kewajiban perpajakannya. Dalam penelitian Ananda et al. (2015), Banamtuan (2018), dan Situmorang et al. (2019) menunjukkan bahwa pemahaman perpajakan berpengaruh positif dan signifikan terhadap kepatuhan wajib pajak orang pribadi.

\section{$\mathrm{H}_{2}$ : Pemahaman Perpajakan berpengaruh positif dan signifikan terhadap Kepatuhan Pelaku E-Commerce Dalam Memenuhi Kewajiban Perpajakan}

Kesadaran wajib pajak adalah kesadaran dalam memahami bahwa pajak adalah sumber penerimaan terbesar, berusaha memahami undangundang dan sanksi dalam peraturan perpajakan, sadar bahwa membayar pajak adalah suatu kewajiban, dan persepsi wajib pajak tentang pelaksanaan sanksi denda PPh (Munari, 2005). Wajib pajak yang sadar dan taat pajak tentunya akan membayar kewajiban perpajakannya tepat waktu dan tepat jumlahnya. Rendahnya kesadaran wajib pajak dapat berpengaruh terhadap kepatuhan wajib pajak. 
Hal tersebut dapat dihubungkan dengan teori kepatuhan (compliance theory), kepatuhan wajib pajak merupakan perilaku yang didasarkan pada kesadaran seorang wajib pajak terhadap kewajiban perpajakannya dengan tetap berlandaskan pada peraturan perundang-undangan yang telah ditetapkan(Tahar \& Rachman, 2014). Menurut teori kepatuhan (compliance theory), kesadaran wajib pajak termasuk dalam komitmen normatif melalui moralitas personal (normative commitment through morality) yang berarti wajib pajak sadar akan pemenuhan kewajiban perpajakannya dan mematuhi hukum karena hukum tersebut dianggap sebagai suatu keharusan (Marlinah, 2018). Sehingga apabila kesadaran wajib pajak terus meningkat, maka kepatuhan wajib pajak juga akan meningkat.

Berdasarkan Theory of Planned Behaviour (TPB), wajib pajak yang telah menyadari pentingnya pajak bagi negara akan termotivasi untuk membayar pajak sesuai dengan aturan perpajakan. Motivasi dan niat yang dimiliki oleh wajib pajak ini berasal dari hati nurani wajib pajak itu sendiri. Bagi wajib pajak yang menyadari bahwa fungsi dari membayar pajak itu sendiri dapat mendukung Anggaran Pendapatan dan Belanja Negara (APBN) maka wajib pajak akan membayar pajaknya tepat waktu.

Indikator yang digunakan untuk mengukur variabel kesadaran wajib pajak diadopsi dan dimodifikasi dari (Priambodo \& Yushita, 2017)yaitu kemauan wajib pajak untuk membayar pajak dan melaporkan SPT serta ketertiban dan kedisiplinan dalam membayar pajak.

Menurut penelitian Alfasadun et al. (2016) kesadaran wajib pajak berpengaruh positif signifikan terhadap kepatuhan wajib pajak. Artinya apabila wajib pajak memiliki kesadaran akan kewajibannya dalam membayar pajak, tentunya akan membuat wajib pajak tersebut patuh. Penelitian Arisandy (2017) dan Sania \& Yudianto (2018) juga menunjukkan adanya pengaruh signifikan antara kesadaran wajib pajak terhadap kepatuhan wajib pajak.

\section{$\mathrm{H}_{3}$ : Kesadaran Wajib Pajak berpengaruh positif dan signifikan terhadap Kepatuhan Pelaku $E$ - Commerce Dalam Memenuhi Kewajiban Perpajakan}

Sanksi pajak dibuat dengan tujuan agar wajib pajak takut untuk melanggar Undang-Undang Perpajakan. Mardiasmo (2011) mengemukakan bahwa sanksi perpajakan merupakan jaminan bahwa ketentuan peraturan perundang-undangan perpajakan (norma perpajakan) akan dituruti, ditaati, dan dipatuhi. Dengan sanksi tersebut diharapkan adanya kesadaran dari wajib pajak untuk meningkatkan kepatuhan perpajakannya.
Berdasarkan teori kepatuhan (compliance theory), sanksi pajak termasuk dalam komitmen normatif melalui legitimasi (normative commitment through legitimacy) yang berarti mematuhi peraturan karena otoritas penyusun hukum tersebut memiliki hak untuk mendikte atau mengikat perilaku (Marlinah, 2018). Teori atribusi juga mendukung pengaruh sanksi pajak terhadap kepatuhan wajib pajak orang pribadi pelaku $e$ commerce dalam memenuhi kewajiban perpajakan. Berdasarkan teori atribusi, sanksi pajak termasuk dalam penyebab eksternal karena adanya pengaruh persepsi wajib pajak dalam membuat penilaian mengenai perilaku kepatuhan wajib pajak dalam melaksanakan kewajiban perpajakan. Sanksi pajak merupakan hal yang diberikan oleh petugas pajak. Wajib pajak yang dikenakan sanksi pajak diharapkan untuk selanjutnya dapat lebih patuh dalam hal pemenuhan kewajiban perpajakannya.

Indikator yang digunakan untuk mengukur variabel sanksi pajak diadopsi dan dimodifikasi dari Kusuma (2017) yaitu sanksi perpajakan yang dikenakan bagi pelanggar aturan cukup berat, pengenaan sanksi pajak yang cukup berat merupakan salah satu sarana untuk mendidik wajib pajak, dan sanksi pajak harus dikenakan kepada pelanggarnya tanpa toleransi.

Penelitian Rusmawati \& Wardani (2015), Karuniawati (2016), Alfasadun et al. (2016), Arisandy (2017), dan Situmorang et al. (2019) membuktikan bahwa sanksi pajak berpengaruh positif dan signifikan terhadap kepatuhan wajib pajak. Tidak sejalan dengan penelitian yang dilakukan Setiyoningrum et al. (2014) dan Dewi \& Merkusiwati (2018) bahwa tidak terdapat pengaruh sanksi perpajakan terhadap kepatuhan wajib pajak.

$\mathrm{H}_{4}$ : Sanksi Pajak berpengaruh
signifikan terhadap
$\begin{aligned} & \text { Kepatuhan } \\ & \text { Commerce Dositif dan } \\ & \text { Perpajakan }\end{aligned}$

\section{METODOLOGI PENELITIAN}

\section{Desain Penelitian}

Penelitian ini menggunakan pendekatan kuantitatif. Objek penelitian adalah wajib pajak $e$ commerce di Kota Semarang pada platform online marketplace Blibli.com. Populasi dari penelitian ini adalah pelaku e-commerce di Kota Semarang yang memasarkan produknya melalui platform online marketplace Blibli.com. Teknik sampling yang digunakan adalah non-probability sampling dengan pemilihan sampel menggunakan metode voluntary sampling dan diperoleh sampel sebanyak 65 responden. Metode voluntary sampling dipilih karena adanya kesulitan mendapatkan responden untuk dijadikan sampel penelitian. Dalam hal ini siapapun yang dipandang memiliki informasi atau data penelitian dan yang bersangkutan dengan 
sukarela mau menjadi narasumber, maka ia dapat dijadikan sampel penelitian (Wahyudin, 2015).

\section{Teknik dan Instrumen Penelitian}

Teknik yang digunakan untuk mengumpulkan data pada penelitian ini menggunakan kuesioner. Kuesioner yang digunakan peneliti berisi pertanyaan tertutup yang alternatif jawabannya telah disediakan oleh peneliti. Adapun skala dan alternative jawaban yang digunakan adalah skala likert dengan empat alternatif (sangat tidak setuju, tidak setuju, setuju, dan sangat setuju).

\section{Teknik Analisis Data}

Teknik pengolahan data dalam penelitian ini menggunakan metode Structural Equation Model (SEM) berbasis Partial Least Square (PLS) dengan alat analisis SmartPLS 3.0. Analisis SEM-PLS dilakukan dengan uji outer model atau model pengukuran untuk menunjukkan seberapa kuat indikator yang digunakan untuk mengukur variabel laten. Outer model meliputi uji reliabilitas dan uji validitas. Analisis SEM-PLS juga dilakukan dengan uji inner model atau model struktural untuk menguji pengaruh variabel laten.

\section{HASIL DAN PEMBAHASAN}

\section{Hasil}

\section{Uji Outer Model atau Model Pengukuran}

Uji outer model digunakan untuk menguji reliabilitas dan validitas. Kriteria yang digunakan untuk menilai outer model yaitu validitas convergent dan reliabilitas.

a. Uji Reliabilitas

Hasil output nilai cronbach's alpha dan composite reliability disajikan dalam tabel berikut.
Tabel 1. Cronbach's Alpha dan Composite

\begin{tabular}{|l|c|c|}
\hline \multicolumn{3}{|c|}{ Reliability } \\
\hline $\begin{array}{l}\text { Kepatuhan } \\
\text { Wajib Pajak } \\
\text { (Y) }\end{array}$ & $\begin{array}{c}\text { Cronbach's } \\
\text { Alpha }\end{array}$ & $\begin{array}{c}\text { Composite } \\
\text { Reliability }\end{array}$ \\
\hline $\begin{array}{l}\text { Sosialisasi } \\
\text { Perpajakan } \\
\left(\mathrm{X}_{1}\right)\end{array}$ & 0,813 & 0,865 \\
\hline $\begin{array}{l}\text { Pemahaman } \\
\text { Perpajakan } \\
\left(\mathrm{X}_{2}\right)\end{array}$ & 0,854 & 0,925 \\
\hline $\begin{array}{l}\text { Kesadaran } \\
\text { Wajib Pajak } \\
\left(\mathrm{X}_{3}\right)\end{array}$ & 0,834 & 0,899 \\
\hline $\begin{array}{l}\text { Sanksi } \\
\text { Perpajakan } \\
\left(\mathrm{X}_{4}\right)\end{array}$ & 0,858 & 0,892 \\
\hline
\end{tabular}

Sumber : Output SmartPLS 3.0, 2019

Berdasarkan uraian tersebut menunjukkan bahwa seluruh variabel memiliki nilai cronbach's alpha dan composite reliability lebih dari 0,7. Sehingga memenuhi syarat untuk reliabilitas (Ghozali, 2011). Nilai tersebut menunjukkan bahwa konsistensi dan stabilitas dari instrumen yang digunakan sangat tinggi, pertanyaan yang diajukan kepada responden untuk mengukur masing-masing variabel merupakan pernyataan yang reliabel.

b. Uji Validitas Convergent

1) Uji Validitas dengan Outer Loading

Nilai loading factor menjadi salah satu kriteria yang digunakan dalam menilai validitas convergent. Ukuran model reflektif dikatakan baik apabila nilai loading factor lebih dari 0,5. Konstruk dengan nilai loading factor kurang dari 0,5 harus dihapus atau didrop agar dapat menghasilkan model yang baik dari sebelumnya (Ghozali, 2011) 


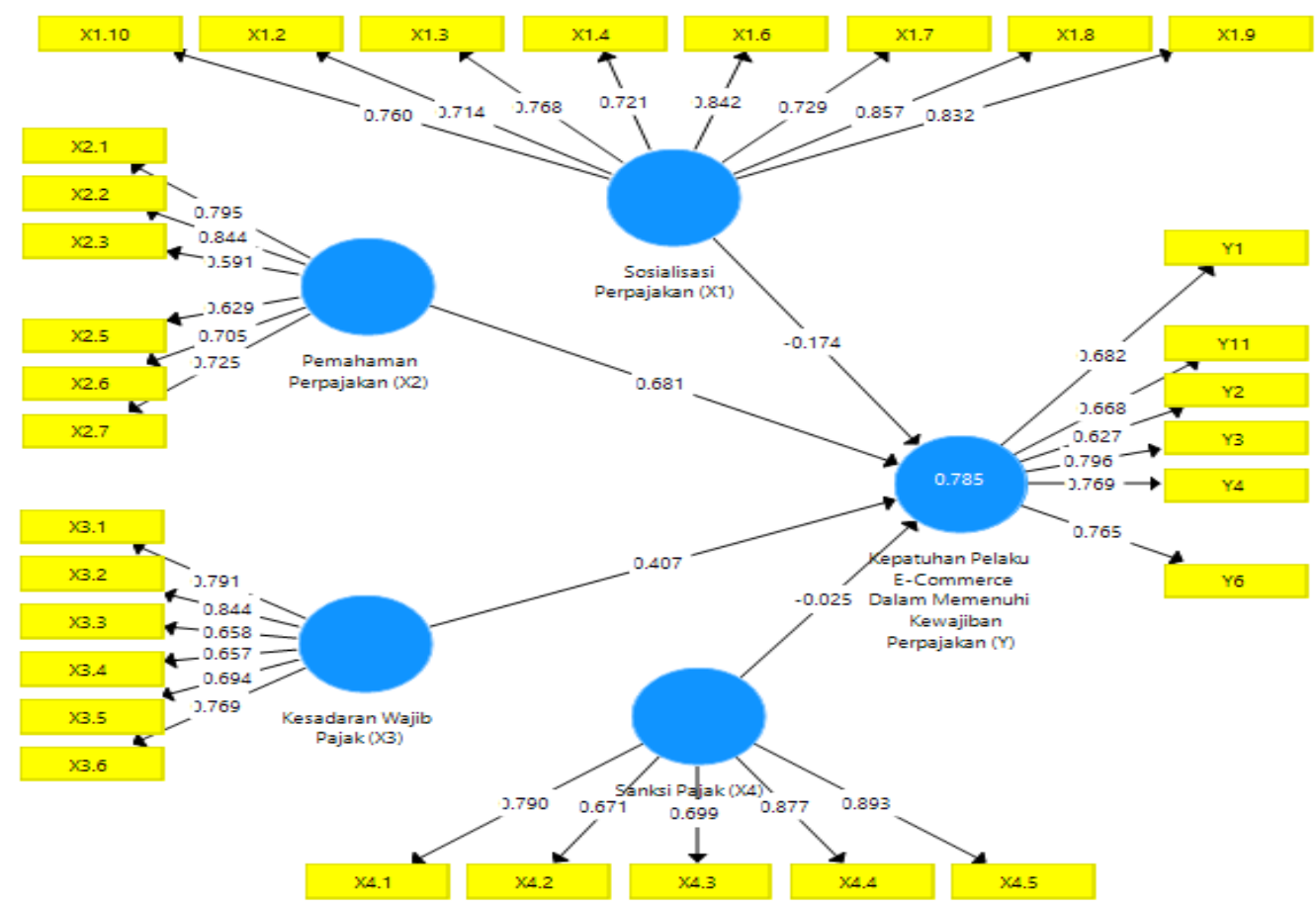

Sumber : Output SmartPLS 3.0, 2019

Gambar 1. Hasil Uji Outer Loading

2) Average Variance Extracted (AVE)

AVE merupakan salah satu parameter yang digunakan untuk menilai convergent validity. Variabel laten dikatakan valid apabila nilai AVE lebih dari 0,5. Nilai AVE direkomendasikan harus lebih besar dari 0,5 mempunyai makna bahwa $50 \%$ atau lebih variance dari indikator dapat dijelaskan (Ghozali \& Latan, 2015). Nilai AVE pada penelitian ini dapat dilihat dalam gambar berikut.

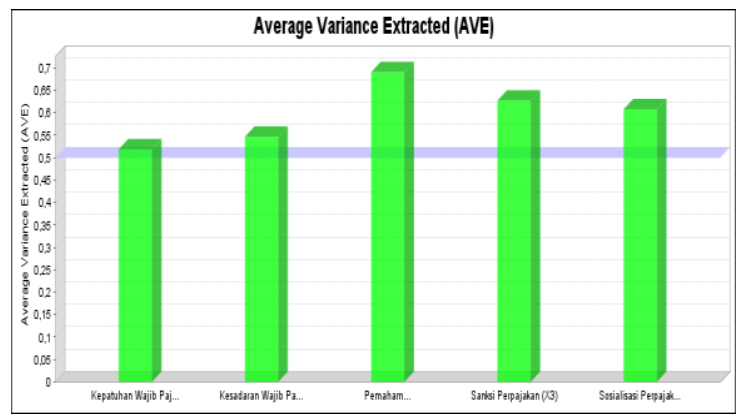

Sumber : Output SmartPLS 3.0, 2019

Gambar 2. Diagram Average Variance Extracted (AVE)

\section{Uji Inner Model atau Model Struktural}

Uji inner model atau model struktural digunakan untuk mengetahui hubungan antar konstruk, nilai signifikansi, dan $R$-Square dari model penelitian.
Penilaian model dengan PLS dapat dimulai dengan melihat $R$-Square untuk variabel laten dependen. Model pengaruh variabel-variabel independen terhadap variabel dependen menunjukkan nilai $R$ Square sebesar 0,733. Hal ini menunjukkan bahwa variabel dependen kepatuhan wajib pajak dijelaskan oleh variabel-variabel independen sebesar $73,3 \%$, sedangkan sisanya yaitu $26,7 \%$ dijelaskan oleh faktor-faktor lain yang tidak dijelaskan dalam model penelitian ini. Berikut adalah hasil pengujian $R$-Square menggunakan alat analisis SmartPLS 3.0.

Tabel 2. Nilai $R$-Square

\begin{tabular}{|l|r|}
\hline & R Square \\
\hline Kepatuhan Wajib Pajak (Y) & 0,733 \\
\hline
\end{tabular}

Sumber : Output SmartPLS 3.0, 2019 


\section{Uji Hipotesis}

Metode pengujian hipotesis dalam penelitian ini menggunakan Structural Equation Model (SEM) berbasis variance dengan menggunakan SmartPLS 3.0. Berikut merupakan hasil pengujian Full Model SEM Algoritm.

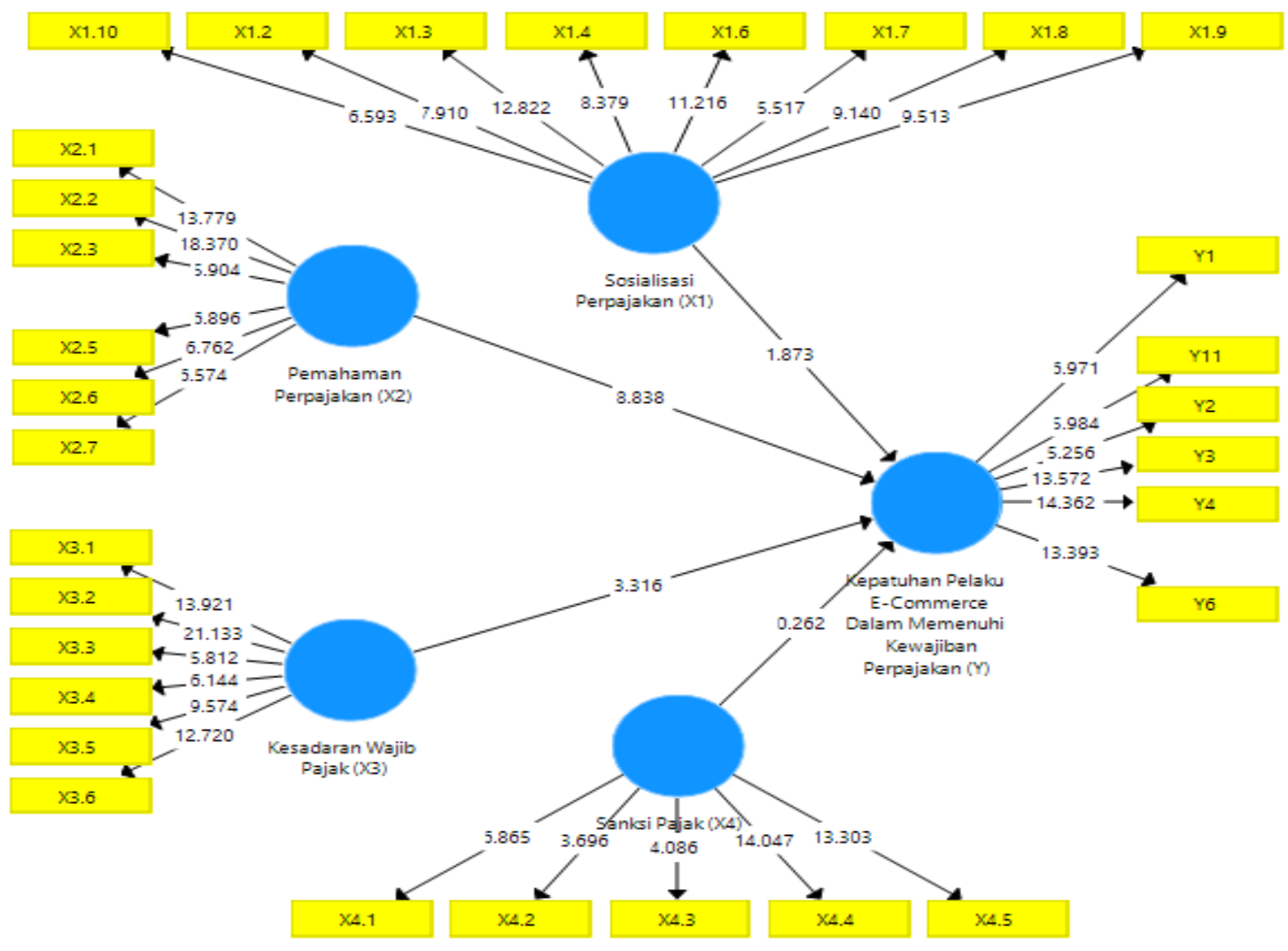

Sumber : Output SmartPLS 3.0, 2019

Gambar 3. Uji Full Model SEM PLS

Penelitian ini menggunakan tingkat keyakinan 95\% dengan tingkat kesalahan 5\%. Uji hipotesis dengan melihat nilai path coefficient yang menunjukkan koefisien parameter dan nilai $t$ statistic. Apabila nilai t-statistic lebih besar dari t- table, maka hipotesis diterima. Nilai t-table untuk hipotesis menggunakan one-tailed adalah >1,96. Berikut tabel hasil pengujian path coefficient dengan aplikasi SmartPLS 3.0.

Tabel 3. Path Coefficient

\begin{tabular}{|l|r|r|r|r|r|}
\hline & \multicolumn{1}{|c|}{$\begin{array}{c}\text { Original } \\
\text { Sample }\end{array}$} & $\begin{array}{c}\text { Sample } \\
\text { Mean }\end{array}$ & $\begin{array}{c}\text { Standard } \\
\text { Deviation }\end{array}$ & T Statistics & \multicolumn{1}{c|}{$\begin{array}{c}\text { P } \\
\text { Values }\end{array}$} \\
\hline $\begin{array}{l}\text { Sosialisasi Perpajakan (X1) -> Kepatuhan } \\
\text { Wajib Pajak (Y) }\end{array}$ & $-0,132$ & $-0,103$ & 0,104 & 1,268 & 0,206 \\
\hline $\begin{array}{l}\text { Pemahaman Perpajakan (X2) -> Kepatuhan } \\
\text { Wajib Pajak (Y) }\end{array}$ & 0,502 & 0,502 & 0,095 & 5,308 & 0,000 \\
\hline $\begin{array}{l}\text { Kesadaran Wajib Pajak(X3) -> Kepatuhan } \\
\text { Wajib Pajak (Y) }\end{array}$ & 0,554 & 0,547 & 0,133 & 4,162 & 0,000 \\
\hline $\begin{array}{l}\text { Sanksi Perpajakan (X4) -> Kepatuhan } \\
\text { Wajib Pajak (Y) }\end{array}$ & 0,015 & 0,010 & 0,099 & 0,149 & 0,881 \\
\hline
\end{tabular}

Sumber : Output SmartPLS 3.0, 2019

Berdasarkan output pengujian hipotesis diatas, maka jawaban untuk setiap hipotesis yang diajukan dalam penelitian ini adalah sebagai berikut:
1) Pengaruh Sosialisasi Perpajakan terhadap Kepatuhan Wajib Pajak 
Berdasarkan hasil uji resampling bootstrapping diperoleh nilai parameter koefisien untuk variabel sosialisasi perpajakan terhadap kepatuhan wajib pajak sebesar -0,132 dengan tstatistic sebesar 1,268. Hal tersebut menunjukkan bahwa sosialisasi perpajakan berpengaruh negatif dan tidak signifikan terhadap kepatuhan wajib pajak dikarenakan nilai t-statistic lebih kecil dari 1,96 (signifikan pada 0,05). Sehingga dapat diambil kesimpulan bahwa $\mathrm{H}_{1}$ ditolak karena sosialisasi perpajakan tidak berpengaruh positif dan signifikan terhadap kepatuhan wajib pajak.

2) Pengaruh Pemahaman Perpajakan terhadap Kepatuhan Wajib Pajak

Berdasarkan hasil uji resampling bootstrapping diperoleh nilai parameter koefisien untuk variabel pemahaman perpajakan terhadap kepatuhan wajib pajak sebesar 0,502 dengan tstatistic sebesar 5,308. Hal tersebut menunjukkan bahwa pemahaman perpajakan berpengaruh terhadap kepatuhan wajib pajak dikarenakan nilai t-statistic lebih besar dari 1,96 (signifikan pada 0,05). Selain itu, pengaruh dari variabel pemahaman perpajakan adalah positif karena nilai parameter koefisiennya adalah positif. Hasil tersebut mengandung arti bahwa variabel pemahaman perpajakan mempunyai hubungan positif dan signifikan. Sehingga dapat diambil kesimpulan bahwa $\mathrm{H}_{2}$ diterima karena pemahaman perpajakan berpengaruh positif dan signifikan terhadap kepatuhan wajib pajak.

3) Pengaruh Kesadaran Wajib Pajak terhadap Kepatuhan Wajib Pajak

Berdasarkan hasil uji resampling bootstrapping diperoleh nilai parameter koefisien untuk variabel kesadaran wajib pajak terhadap kepatuhan wajib pajak sebesar 0,554 dengan tstatistic sebesar 4,162. Hal tersebut menunjukkan bahwa kesadaran wajib pajak berpengaruh terhadap kepatuhan wajib pajak dikarenakan nilai t-statistic lebih besar dari 1,96 (signifikan pada 0,05). Selain itu, pengaruh dari variabel kesadaran wajib pajak adalah positif karena nilai parameter koefisiennya adalah positif. Hasil tersebut mengandung arti bahwa variabel kesadaran wajib pajak mempunyai hubungan positif dan signifikan. Sehingga dapat diambil kesimpulan bahwa $\mathrm{H}_{3}$ diterima karena kesadaran wajib pajak berpengaruh positif dan signifikan terhadap kepatuhan wajib pajak.

4) Pengaruh Sanksi Perpajakan terhadap Kepatuhan Wajib Pajak

Berdasarkan hasil uji resampling bootstrapping diperoleh nilai parameter koefisien untuk variabel sanksi perpajakan terhadap kepatuhan wajib pajak sebesar 0,015 dengan t-statistic sebesar 0,149. Hal tersebut menunjukkan bahwa sanksi perpajakan mempunyai hubungan positif namun tidak signifikan terhadap kepatuhan wajib pajak dikarenakan nilai t-statistic lebih kecil dari 1,96 (signifikan pada 0,05). Sehingga dapat diambil kesimpulan bahwa $\mathrm{H}_{4}$ ditolak karena sanksi perpajakan berpengaruh positif namun tidak signifikan terhadap kepatuhan wajib pajak.

\section{Pembahasan}

Faktor pertama yang mempengaruhi kepatuhan wajib pajak orang pribadi pelaku $e$ commerce dalam memenuhi kewajiban perpajakan adalah sosialisasi perpajakan. Kepatuhan Wajib Pajak akan dapat ditingkatkan jika kegiatan sosialisasi dilakukan dengan tepat, untuk itu diperlukan upaya kegiatan sosialisasi yang lebih efektif dan efisien. Menurut Surat Edaran Nomor SE - 22/PJ/2007 tentang penyeragaman sosialisasi bagi masyarakat dapat dilakukaan melalui: call center pajak, penyuluhan, internet, petugas pajak, televisi, dan iklan baris.

Faktor kedua yang mempengaruhi kepatuhan wajib pajak orang pribadi pelaku e-commerce dalam memenuhi kewajiban perpajakan adalah pemahaman perpajakan. Berdasarkan teori atribusi pemahaman wajib pajak tentang peraturan perpajakan merupakan faktor internal yang dapat mempengaruhi persepsi wajib pajak dalam membuat keputusan terkait perilaku kepatuhan wajib pajak dalam melaksanakan kewajiban perpajakan. Perilaku kepatuhan ini dapat tumbuh dari pribadi wajib pajak sendiri, karena tingkat pengetahuan yang dimiliki oleh wajib pajak. Semakin tinggi tingkat pengetahuan perpajakan yang dimiliki seorang wajib pajak tentunya akan semakin patuh terhadap pemenuhan kewajiban perpajakannya.

Faktor ketiga yang mempengaruhi kepatuhan wajib pajak orang pribadi pelaku e-commerce dalam memenuhi kewajiban perpajakan adalah kesadaran wajib pajak. Kesadaran wajib pajak tergantung pada individual masing-masing, baik melalui pengamatan dari orang lain maupun pengalaman pribadi. Berdasarkan Theory of Planned Behaviour (TPB), wajib pajak yang telah menyadari pentingnya pajak bagi negara akan termotivasi untuk membayar pajak sesuai dengan aturan perpajakan. Motivasi dan niat yang dimiliki oleh wajib pajak ini berasal dari hati nurani wajib pajak itu sendiri. Semakin tinggi tingkat kesadaran wajib pajak tentunya akan semakin patuh terhadap pemenuhan kewajiban perpajakannya.

Faktor keempat yang mempengaruhi kepatuhan wajib pajak orang pribadi pelaku $e$ commerce dalam memenuhi kewajiban perpajakan adalah sanksi pajak. Berdasarkan teori kepatuhan (compliance theory) seorang individu cenderung mematuhi hukum yang mereka anggap sesuai dan konsisten dengan norma-norma internal mereka. Sanksi pajak termasuk dalam komitmen normatif melalui legitimasi (normative commitment through legitimacy) yang berarti mematuhi peraturan karena otoritas penyusun hukum tersebut memiliki hak untuk mendikte atau mengikat perilaku. Semakin 
ketat sanksi yang diberikan semakin tinggi juga pengaruh dari luar terhadap kepatuhan wajib pajak dalam menyelesaikan kewajiban perpajakannya.

\section{KESIMPULAN}

Berdasarkan hasil pengujian dan pembahasan, dapat ditarik kesimpulan sebagai berikut:

1. Sosialisasi Perpajakan berpengaruh negatif dan tidak signifikan terhadap Kepatuhan Pelaku ECommerce Dalam Memenuhi Kewajiban Perpajakan.

2. Pemahaman Perpajakan berpengaruh positif dan signifikan terhadap Kepatuhan Pelaku ECommerce Dalam Memenuhi Kewajiban Perpajakan.

3. Kesadaran Wajib Pajak berpengaruh positif dan signifikan terhadap Kepatuhan Pelaku ECommerce Dalam Memenuhi Kewajiban Perpajakan.

4. Sanksi Pajak berpengaruh positif namun tidak signifikan terhadap Kepatuhan Pelaku ECommerce Dalam Memenuhi Kewajiban Perpajakan.

Berdasarkan hasil penelitian yang telah dipaparkan sebelumnya, maka saran yang dapat diberikan yaitu:

1. Bagi Wajib Pajak Pelaku E-Commerce

Saran kepada Wajib Pajak pelaku e-commerce yaitu agar lebih peduli kepada negara dengan cara menjadi Wajib Pajak yang patuh pada peraturan perpajakan dan penelitian ini diharapkan dapat memberikan masukan bagi Wajib Pajak untuk lebih memahami dan menyadari pentingnya meningkatkan kepatuhan dalam membayar kewajiban pajak sehingga dapat terus berkontribusi terhadap peningkatan pendapatan dan pembangunan Negara.

2. Bagi Otoritas Pajak

Saran yang diberikan kepada Otoritas Pajak yaitu untuk terus meningkatkan sosialisasi terhadap Wajib Pajak khususnya sektor $e$ commerce atau bisnis online dengan penyampaian informasi yang mudah dipahami oleh Wajib Pajak. Otoritas Pajak juga perlu mempertimbangkan secara matang penetapan sanksi pajak yang akan dikenakan bagi Wajib Pajak yang tidak patuh dan sanksi tersebut juga perlu disosialisasikan agar Wajib Pajak memahami hal-hal yang berkaitan dengan pelaksanaan sanksi pajak.

3. Bagi Peneliti Selanjutnya

Penelitian selanjutnya diharapkan dapat memperluas objek penelitian dan menambah variabel-variabel lain untuk mendukung hasil penelitian agar lebih baik.

\section{REFERENSI}

Ajzen, I. (1991). Organizational Behavior and Human Decision Processes 50, 179-211 (1991). 211, 179-211.

Alfasadun, Hardiningsih, P., \& Rachmawati. (2016). Coaching Taxpayers Policy (Tpwp) and Tax Penalties Against Tax Compliance. Proceedings-International Conference of Banking, Accounting, Management and Economics \& Call For Papers (ICOBAME), October 26-27, 2016, Magelang, Indonesia, 978-979.

Ananda, P. R. D., Kumadji, S., \& Husaini, A. (2015). Pengaruh Sosialisasi Perpajakan, Tarif Pajak, dan Pemahaman Perpajakan Terhadap Kepatuhan Wajib Pajak (Studi Pada Umkm Yang Terdaftar Sebagai Wajib Pajak di Kantor Pelayanan Pajak Pratama Batu). Jurnal Perpajakan $(J E J A K)$ perpajakan.studentjournal.ub.ac.id, Vol. 6 No. https://doi.org/10.1377/hlthaff.2013.0625

Arisandy, N. (2017). Pengaruh Pemahaman Wajib Pajak, Kesadaran Wajib Pajak Dan Sanksi Pajak Terhadap Kepatuhan Wajib Pajak Orang Pribadi Yang Melakukan Kegiatan Bisnis Online Di Pekanbaru. Jurnal Ilmiah Ekonomi dan Bisnis, 14(1), 62-71.

Banamtuan, O. (2018). Pengaruh Sosialisasi Perpajakan Terhadap Kepatuhan WPOP dalam Pemenuhan Kewajiban $\mathrm{PPh} 21$. Jurnal Penelitian Teori dan Terapan Akuntansi, 3(2), $1-10$.

Clement, J. (2019). Penjualan E-Commerce Ritel Global 2014-2021.

Dewi, G. A. P. I. P., \& Merkusiwati, N. K. L. A. (2018). Faktor-Fator yang Memengaruhi Tingkat Kepatuhan Wajib Pajak Orang Pribadi di KPP Pratama Badung Utara. E-Jurnal Akuntansi, $23, \quad 1277$. https://doi.org/10.24843/eja.2018.v23.i02.p18

Ghozali, I. (2011). Structural Equation Modeling; Metode Alternatif dengan Partial Least Square: PLS. Semarang: Badan Penerbit Universitas Diponegoro.

Ghozali, I., \& Latan, H. (2015). Partial Least Squares: Concepts, Technique, and Application use SmartPLS 3.0 Program. Edition 2. Semarang: Undip.

Heider, F. (1958). The Psychology of Interpersonal Relations. New York: Wiley.

Herryanto, M., \& Toly, A. A. (2013). Pengaruh kesadaran wajib pajak, kegiatan sosialisasi 
perpajakan, dan pemeriksaan pajak terhadap penerimaan pajak. Accounting and Tax review, l(1), 125-135.

Jannah, S. Z. (2016). Pengaruh Pengetahuan, Penghasilan, Manfaat Atas NPWP, Sanksi, dan Sosialisasi Terhadap Kepatuhan Pemilik UMKM Dalam Memiliki NPWP (Studi di KPP Pratama Surakarta). https://doi.org/10.1109/ciced.2018.8592188

Kamil, N. I. (2015). The Effect of Taxpayer Awareness , Knowledge , Tax Penalties and Tax Authorities Services on the Tax Complience: ( Survey on the Individual Taxpayer at Jabodetabek \& Bandung ). Research Journal of Finance and AccountingOnline), 6(2), 104-112.

Karuniawati, S. (2016). Pengaruh Pengetahuan Perpajakan, Kesadaran Pajak, dan Sanksi Pajak Terhadap Kepatuhan Wajib Pajak Orang Pribadi Yang Melakukan Kegiatan Usaha. Artikel Ilmiah, 1-13.

Kevin, A. (2019). Miris! Ternyata Tax Ratio Indonesia Terendah di Asia Pasifik.

Kusuma, K. C. (2017). Pengaruh Kualitas Pelayanan Pajak, Pemahaman Peraturan Perpajakan serta Sanksi Perpajakan terhadap Kepatuhan WPOP. 1-14.

Mardiasmo. (2011). Perpajakan. Jakarta: CV Andi Offset.

Marlinah, A. (2018). Pengaruh Pengetahuan dan Kesadaran Terhadap Kepatuhan Wajib Pajak Kendaraan Bermotor Dengan Sanksi Perpajakan Sebagai Variabel Moderating (Studi Pada Kantor Samsat Wilayah I Kota Makassar). Jurnal. STIE Nobel Indonesia Makassar.

Milgram, S. (1963). Behavioral Study of obedience. Journal of Abnormal and Social Psychology, 67(4), 371-378. https://doi.org/10.1037/h0040525

Munari. (2005). Pengaruh Faktor Tax Payer Terhadap Keberhasilan Penerimaan Pajak Penghasilan (Studi Kasus KPP Pratama Batu, Malang). Jurnal Eksekutif, Vol. 2, No. 2.

Priambodo, P., \& Yushita, A. N. (2017). Pengaruh Pemahaman Peraturan Pajak, Sanksi Perpajakan, dan Kesadaran Wajib Pajak
Terhadap Kepatuhan Wajib Pajak Orang Pribadi di Kantor Pelayanan Pajak Pratama Kabupaten Purworejo pada Tahun 2017. Jurnal Profita, Vol 5 No.5(2), 1-16.

Rusmawati, S., \& Wardani, D. K. (2015). Pengaruh Pemahaman Pajak, Sanksi Pajak, Dan Sensus Pajak Terhadap Kepatuhan Wajib Pajak Pribadi Yang Memiliki Usaha. Jurnal Akuntansi, 3(2), 75-91. https://doi.org/10.24964/ja.v3i2.53

Sania, A. F., \& Yudianto, I. (2018). Analysis of Factors that Influence Taxpayers Compliance in Fulfilling their Taxation Obligations: Study of Small Medium Entrepreneur (SMEs) Taxpayers Based on eCommerce in the Bandung Area. Journal of Accounting Auditing and Business, $1(2), \quad 17$. https://doi.org/10.24198/jaab.v1i2.18270

Saragih, S. F. (2013). Analisis Pengaruh Sosialisasi Perpajakan, Kualitas Pelayanan Fiskus Dan Sanksi Perpajakan Terhadap Kepatuhan Wajib Pajak Orang Pribadi Di Kantor Pelayanan Pajak (KPP) Pratama Medan Timur. Skripsi $U S U$, Fakultas $E$ (http://repository.usu.ac.id/handle/123456789 139496).

Setiyoningrum, A. T., Tinangon, J., \& Wokas, H. R. N. (2014). Analisis Pengaruh Sosialisasi Perpajakan, Kualitas Pelayanan Fiskus dan Sanksi Perpajakan Terhadap Kepatuhan Wajib Pajak Orang Pribadi di Kantor Pelayanan Pajak Pratama Manado. Jurnal Riset Akuntansi, Vol 9, No., 50-62.

Situmorang et al. (2019). The Effect of Tax Examination, Tax Administration Sanctions, Understanding Taxation, and Tax Employment (Tax Amnesty) on Compulsory Tax Compliance Personal at KPP Pratama Medan Polonia. Journal of Public Budgeting, Accounting, And Finance, Vol 2 No.1.

Tahar, A., \& Rachman, A. K. (2014). Pengaruh Faktor Internal dan Faktor Eksternal Terhadap Kepatuhan Wajib Pajak. Jurnal Akuntansi dan Investasi, 15(1), 56-67.

Wahyudin, A. (2015). Metodologi Penelitian. Semarang. 